УДК 378:796 - 051

DOI:

Сергій Карассвич, кандидат педагогічних наук, викладач кафедри спортивних дисциилін Уманського державного педагогічного університету імені Павла Тичини

\title{
ДОСЛІДНО-ЕКСПЕРИМЕНТАЛЬНА РОБОТА 3 ФОРМУВАННЯ ГОТОВНОСТІ МАЙБУТНІХ УЧИТЕЛІВ ФІЗИЧНОЇ КУЛЬТУРИ ДО ФІЗКУЛЬТУРНО- СПОРТИВНОЇ ДІЯЛЬНОСТІ В ЗАКЛАДАХ СЕРЕДНЬОЇ ОСВІТИ
}

У статті розкрито методику проведення дослідно-експериментальної роботи з формування готовності майбутніх учителів фізичної культури до фізкультурно-спортивної діяльності в закладах середньої освіти. Розроблено Програму формувального експерименту. Проведено дослідження з визначення рівня готовності студентів до фізкультурно-спортивної роботи за критеріями та проведено діагностику його показників. Доведено ефективність запропонованих нововведень у напрямі підготовки майбутніх учителів фізичної культури до фізкультурно-спортивної діяльності в загальноосвітніх навчальних закладах.

Ключові слова: дослідно-експериментальна робота, фізкультурно-спортивна діяльність, формування готовності майбутніх учителів фізичної культури, підготовка майбутніх учителів фізичноі культури до фізкультурно-спортивної діяльності, заклади середньої освіти.

Рис. 4. Табл. 1. Літ. 8.

Serhiy Karasyevych, Ph. D. (Pedagogy), Lecturer of the Sports Disciplines Department Uman Pavlo Tychyna State Pedagogical University

\section{EXPERIMENTAL WORK ON FORMATION OF READINESS OF FUTURE TEACHERS OF PHYSICAL CULTURE TO SPORTS ACTIVITIES IN INSTITUTIONS OF SECONDARY EDUCATION}

The article discloses the technique of carrying out of experimental work on formation of readiness of future teachers of physical culture to sports activities in secondary educational institutions. The developed program of forming experiment included: conducting a diagnosis of the levels of readiness of future teachers of physical culture to sports activities in secondary schools, development of curricula aimed at the training of future teachers of physical culture and implementation of training and methodological support: update content of the discipline "Theory and methodology of physical education"; agreement "through the" disciplines of basic physical training and sports: "track and field teaching methods", "Gymnastics with methodology of teaching", "Sports games teaching methods", "Outdoor games with teaching methods", "Ski sport with the method of training", "Swimming with methods of teaching", specsummary "Organization and technique of carrying out sports activities in secondary schools"; the intensification of independent work of future teachers to gain knowledge and skills of physical and sports activities. The article discloses the methodology of experimental work on formation of readiness of students to physical culture and sports work during classroom and extracurricular work. The main task is to determine the level of readiness of students to physical culture and sports work on criteria and to conduct a diagnosis of its performance. The author proves the effectiveness of the proposed innovations in the field of training of future teachers of physical culture to sports activities in secondary schools.

Keywords: experimental work, sports activities, the formation of readiness of future teachers of physical culture, the training of future teachers of physical culture to sports activities, the institutions of secondary education.

П остановка проблеми. Вивчення проблем формування готовності майбутніх учителів фізичної культури до фізкультурно-спортивної діяльності в закладах середньої освіти призвело до необхідності проведення експериментальної роботи з метою виявлення, обгрунтування та перевірки ефективних шляхів здійснення цього процесу.

Для виконання поставлених завдань розроблено експериментальну програму, в основу створення якої були покладені уявлення про механізми і психолого-педагогічні складові цього процесу. Експериментальна програма формування готовності майбугніх учителів фізичної культури до фізкультурно-спортивної діяльності в закладах середньої освіти включала формувальний експеримент, який передбачав проведення методики діагностування рівнів готовності майбутніх учителів фізичної культури до фізкультурно-спортивної діяльності у загальноосвітніх навчальних закладах, розробці авторських навчальних програм, спрямованих на підготовку майбутніх учителів фізичної культури та реалізацію навчально-методичного забезпечення: 


\section{ДОСЛІДНО-ЕКСПЕРИМЕНТАЛЬНА РОБОТА 3 ФОРМУВАННЯ ГОТОВНОСТІ МАЙБУТНІХ УЧИТЕЛІВ ФІЗИЧНОЇ КУЛЬТУРИ ДО ФІЗКУЛЬТУРНО-СПОРТИВНОЇ ДІЯЛЬНОСТІ В ЗАКЛАДАХ СЕРЕДНЬОЇ ОСВІТИ}

оновлення змісту дисципліни “Теорія і методика фізичного виховання"; узгодження "наскрізних тем” дисциплін базових фізкультурно-спортивних видів: “Легка атлетика 3 методикою навчання", "Гімнастика з методикою навчання", “Спортивні ігри з методикою навчання”, “Рухливі ігри 3 методикою навчання", “Лижний спорт 3 методикою навчання”, "Плавання $з$ методикою навчання”, проведення спецсемінару “Організація і методика проведення фізкультурно-спортивної діяльності в загальноосвітніх навчальних закладах"; активізації самостійної роботи майбутніх учителів для отримання знань та умінь фізкультурно-спортивної роботи.

У експериментальних групах студенти займалися фізичною культурою за встановленим навчальним планом для закладів вищої освіти, 3 використанням рухливих ігор, занять в тренажерномузалі, шейпінгом, волейболом тощо. Заняття в експериментальній групі доповнювалися фізкультурно-спортивною діяльністю різноманітного характеру. Заняття фізичною культурою в контрольних групах проводилося за стандартною програмою фізичного виховання в закладах вищої освіти.

Для проведення дослідно-експериментальної роботи розв'язувалися завдання 3 виявлення характеру впливу експериментальних чинників на рівень готовності майбутнього вчителя фізичної культури до фізкультурно-спортивної діяльності учнів.

Формувальний експеримент проходив в природних умовах освітнього процесу за типом варіативного, для якого характерно цілеспрямоване варіювання в різних групах 3 вирівняними початковими умовами окремих параметрів, що піддаються дослідженню, i порівняння кінцевих результатів.

Для вирішення діагностичних завдань використовувалися методи: тестування, анкетування, метод експертних оцінок, спостереження, бесіда, аналіз продуктів навчальної діяльності студентів та такі методики: діагностичний опитувальник Є. Климова, методика Е. Фанталової, Н. Стамбулової, Д. Роттера, Ю. Ханіна, Р. Амтхауера, тести завдання, адаптовані відповідно до запропонованої концепції структури педагогічної діяльності Н. Кузьміної, І. Решетень, М. Прохорової, методика А. Киверялга [1 - 8].

Мета статті - розкрити методику проведення дослідно-експериментальної роботи з формування готовності майбутніх учителів фізичної культури до фізкультурно-спортивної діяльності в закладах середньої освіти та довести ії ефективність.
Результати дослідження. На основі вимог нормативних документів і результатів аналізу психолого-педагогічної літератури з урахуванням передового педагогічного досвіду і висновків попереднього етапу експерименту розроблено Програму формувального експерименту:

1) озброєння студентів необхідними знаннями 3 фізкультурно-спортивної діяльності та спеціальними вміннями в галузі фізичного виховання через оновлення змісту дисципліни “Теорія і методика фізичного виховання"; узгодження “наскрізних тем” дисциплін базових фізкультурно-спортивних видів: “Легка атлетика з методикою навчання”, “Гімнастика з методикою навчання”, “Спортивні ігри 3 методикою навчання", "Рухливі ігри з методикою навчання", “Лижний спорт 3 методикою навчання”, “Плавання 3 методикою навчання”, проведення спецсемінару “Організація і методика проведення фізкультурно-спортивної діяльності в загальноосвітніх навчальних закладах";

2) підготовка і проведення різних форм фізкультурно-спортивної роботи на практичних заняттях 3 дисциплін базових фізкультурноспортивних видів в академічних групах (заняття проводилися за принципом навчальної практики 3 подальшим аналізом: усі студенти виступали як в ролі викладача, так і в ролі учня);

3) проведення аудиторних і позааудиторних фізкультурно-спортивних заходів, спрямованих на набуття студентами навичок використання різноманітних форм і методів організації фізкультурно-спортивної роботи з дітьми різного віку від молодших школярів до випускників загальноосвітніх навчальних закладів;

4) створення проблемних ситуацій і організація ділових ігор на практичних заняттях з метою моделювання сценаріїв фізкультурно-спортивних заходів $з$ дітьми різного шкільного віку;

5) організація практичної і самостійної роботи в галузі фізичного виховання 3 учнями в ході педагогічної практики в загальноосвітніх навчальних закладах.

Виклад основного матеріалу. Дослідноекспериментальне дослідження щодо формування готовності студентів до фізкультурно-спортивної роботи здійснювалося нами в ході аудиторної та позааудиторної роботи. 3 одного боку, це лекційні заняття, активне включення в дослідницьку роботу (написання доповідей і рефератів), а 3 іншого цілеспрямовано організовані практичні заняття 3 дисциплін базових фізкультурноспортивних видів, позааудиторні спортивномасові факультетські і університетські заходи (участь в змаганнях, організація і проведення 


\section{ДОСЛІДНО-ЕКСПЕРИМЕНТАЛЬНА РОБОТА 3 ФОРМУВАННЯ ГОТОВНОСТІ МАЙБУТНІХ УЧИТЕЛІВ ФІЗИЧНОЇ КУЛЬТУРИ ДО ФІЗКУЛЬТУРНО-СПОРТИВНОЇ ДІЯЛЬНОСТІ В ЗАКЛАДАХ СЕРЕДНЬОЇ ОСВІТИ}

турпоходів тощо). Щоб домогтися високого рівня інтересу до фізкультурно-спортивної діяльності у студентів, ігрові заняття (спортивні, рухливі ігри) регулярно поєднувалися із засобами інших видів спорту: легкої атлетики, гімнастики, акробатики тощо. Зокрема, ігрові прийоми, техніко-тактичні дії відпрацьовувалися в поєднанні з різними акробатичними вправами, які вимагають від студентів добре розвиненої координації рухів, спритності, гнучкості та інших якостей. На всіх заняттях широко застосовувалися засоби загальної і спеціальної підготовки. На відміну від традиційної програми в практичній підготовці широко використовувалися естафети 3 елементами волейболу, різноманітні рухливі ігри, а також проведення навчальних ігор.

У формуванні висококваліфікованого педагога значна роль відводилася самостійній роботі. Включення студентів у самостійну роботу передбачало формування у них прийомів самостійної діяльності, виховання культури розумової праці, а також розвиток навичок самовиховання і самопідготовки.

Для визначення рівня сформованості мотиваційно-ціннісного критерію готовності студентів до фізкультурно-спортивної роботи проведено діагностику його показників. Основними методами мотиваційної підтримки майбутніх учителів у ході реалізованої експериментальної програми виступали аналіз проблемних ситуацій, пізнавальних завдань, включення студентів в особистісно-смисловий діалог, рольові ігри.

Результати проведеного аналізу довели, що “ $69,7 \%$ студентів ЕГ виявили інтерес до занять фізичною культурою та спортом під час аудиторної роботи і 74,3 \% п позааудиторної. Найбільші цифрові дані отримані при відповіді на прояв інтересу до покращення свого - 81,4 \%. У контрольній групі відповідно - 31,4 \%, 29,6 \%, $40,1 \%$.

За час формувального експерименту в експериментальній групі зріс рівень інтересу до спортивно-масових заходів і до видів спорту, включених в їх зміст. Після проведеного експерименту в експериментальній групі зріс інтерес до нетрадиційних видів спорту (ЕГ $87,4 \%$, КГ - 54,9\%). Високим відсотком значущості було оцінено істотну роль спортивномасових заходів в аспекті позитивного впливу на моральні якості і естетичні здібності (ЕГ - 79,6 \%, КГ - 38,4\%).

Проведений етап формувального експерименту показав, що відбулися зміни у ставленні студентів ЕГ до здійснення фізкультурно-спортивної діяльності. Динаміка результатів діагностики ставлення студентів до здійснення фізкультурноспортивної діяльності показала, що в КГ істотних змін не відбулося (індиферентне ставлення змінилося із $25,5 \%$ до $24,0 \%$ ), в експериментальній групі знизився відсоток індиферентного ставлення до фізкультурноспортивної діяльності (з 28,0 \% до 16,1%). У ЕГ відбулося збільшення числа студентів, які позитивно ставляться до організації та проведення фізкультурно-спортивної роботи в загальноосвітніх навчальних закладах ( 3 45,2 до 71,6 \%).

Під час формувального експерименту здійснювалася перевірка сформованості мотивів і ціннісних орієнтацій студентів. Аналіз даних доводить, що у студентів ЕГ сформованість мотивів і ціннісного ставлення до творчого прояву професійної діяльності перебуває на високому рівні: мотиви отримання спеціальних фізкультурно-спортивних знань - 50,8\%, мотивація до навчально-пізнавальної діяльності $50,3 \%$, мотиви до фізкультурно-спортивної діяльності - 51,6 \%, ціннісне ставлення до творчого прояву професійної діяльності - 50,1%. У студентів КГ переважає середній рівень сформованості мотивів і ціннісного ставлення, що складає відповідно $\quad 60,0$ \%, 64,5 \%, 61,9\%, $61,0 \%$.

Для виявлення сформованості ціннісних орієнтацій до фізкультурно-спортивної діяльності використано метод ранжування життєвих цінностей. Аналіз даних показав, що на перше місце студенти ЕГ поставили “здоров'я”, КГ “житло”; на друге (ЕГ) - “цікаву роботу”, КГ “любов”; на третє (ЕГ) - “любов”, КГ “здоров’я”; далі виділено такі цінності: кар'єра, творчість, автомобіль та інші відповіді.

Результати співбесід, анкетування, аналізу самооцінки та експертної оцінки дозволили зробити такі узагальнення:

- більшість студентів ЕГ (80,4 \%) та 43,3 \% КГ вважають важливим розвиток фізкультурної освіти, 76,3 \% ЕГ, 41,8 \% КГ визнають свою роль у процесі проведення спортивних занять, 70,2 \% ЕГ, 30,4 \% КГ розуміють і усвідомлюють необхідність збереження спортивних традицій, що виражено в таких відповідях: “відводжу велику роль вчителю в збереженні і розвитку спортивних традицій”, “бачу необхідність розвитку спортивних здібностей у школярів" тощо;

- 69,9\% респондентів ЕГ та 36,2 \% КГ мають бажання вивчати, зберігати та розвивати спортивні досягнення, що виражено в таких відповідях: “маю бажання зберігати спортивну спадщину” тощо; 


\section{ДОСЛІДНО-ЕКСПЕРИМЕНТАЛЬНА РОБОТА 3 ФОРМУВАННЯ ГОТОВНОСТІ МАЙБУТНІХ УЧИТЕЛІВ ФІЗИЧНОЇ КУЛЬТУРИ ДО ФІЗКУЛЬТУРНО-СПОРТИВНОЇ ДІЯЛЬНОСТІ В ЗАКЛАДАХ СЕРЕДНЬОЇ ОСВІТИ}

- $69,8 \%$ студентів ЕГ та $30,1 \%$ КГ усвідомлюють своє призначення, мають бажання укріплювати спортивний рівень учнів, що підтверджується такими відповідями “подобається робота в загальноосвітніх навчальних закладах", “бачу необхідність розвитку спорту в загальноосвітніх навчальних закладах і в мікрорайоні” тощо.

Можемо констатувати, що більшість студентів експериментальних груп виявили впевненість в причетності до процесу збереження, розвитку спортивних традицій і прагнення до самостійної, цілеспрямованої, соціально-значимої діяльності в умовах загальноосвітніх навчальних закладах $\mathrm{i}$ освіти в цілому.

Результатом проведеного експерименту стало зміщення акценту в постановці цілей занять фізичної культури і участі в спортивно-масових заходах. На перший план студенти експериментальної групи поряд 3 мотивом зберегти і поліпшити здоров'я, висувають і такі мотиви, як розширення сфери спілкування, поліпшення статури, розвиток інтелекту, розвиток здатності бачити красу і підвищення рівня культури. Аналіз даних доводить, що домінівною метою занять фізичною культурою і спортом студентів ЕГ за результатами формувального експерименту є зміцнення здоров'я $(80,2$ \%), КГ - 40,1\%, бажання стати більш фізично розвиненим (ЕГ - 80,0\%, КГ - 23,4\%), поліпшити статуру (ЕГ - 78,3\%, КГ - 25,8 \%).

Анкетне опитування показало, що у студентів експериментальної групи достовірно змінилася оцінка можливостей при активних заняттях фізичною культурою і спортом. Зазначається достовірна зміна індексу значущості при виборі таких показників, як активні заняття фізичною культурою, розвиток своїх естетичних здібностей, підвищення рівня культури.

Здійснений аналіз виконаних завдань (опитування, анкетування, тестування) 3 визначення рівня готовності майбутніх учителів до фізкультурно-спортивної діяльності за мотиваційно-ціннісним критерієм у КГ становить (в балах): $\mathrm{H}_{\mathrm{K}}^{0}=2,91$; $\mathrm{E} \Gamma-\mathrm{H}_{\mathrm{e}}{ }^{0}=3,8$. Різниця між ними склала $17,8 \%$, яка на етапі формувального експерименту є істотною.

Наочно отримані результати відображено на рис. 1.

Аналіз рисунку 1 наочно доводить наявність сугтєвої різниці між показниками сформованості мотиваційно-ціннісного критерію готовності студентів до фізкультурно-спортивної діяльності у обох групах.
Сформованість інтелектуально-пізнавального критерію передбачала отримання фахових знань студентами, які вони набували в процесі вивчення дисциплін, у відповідності до навчального плану.

Для з'ясування рівня методичної готовності студентів до фізкультурно-спортивної діяльності використано метод експертних оцінок. Аналіз даних доводить, що найвищі результати студенти ЕГ отримали за знання про проведення бесіди щодо доцільності фізичної культури (80,4%), проведення фізкультурно-оздоровчих заходів (ЕГ 79,8 \%), складання комплексу гімнастики до занять (74,2 \%), у студентів КГ відповідно 39, 1 \%, $37,1 \%, 31,8 \%$.

Наявність системи спеціальних технологічних знань перевірялася за допомогою тесту, який включав в себе питання 3 техніки та методики навчання окремим руховим діям в гімнастиці, легкій атлетиці, лижній підготовці тощо. Аналіз даних показав, що студенти ЕГ найбільше володіють технологічними знаннями з гімнастики $(81,5 \%)$ та баскетболу $(80,3 \%)$, студенти КГ гімнастики (52,3 \%) та волейболу $(51,4 \%)$.

Для формування теоретичної готовності студентів проведено цикл занять, на якому вивчалися такі проблеми: фізкультурно-спортивна у загальноосвітній школі; фахові знання, практичні уміння і навички в майбутній професійній діяльності вчителя фізичної культури; роль спорту у вирішенні проблеми оздоровлення нації. Для того, щоб підготувати студентів до фізкультурно-спортивної діяльності в закладах середньої освіти, додатково проведено заняття 3 таких тем: "Комплектування груп та організація занять у спортивних секціях”, “Особливості тренувальних занять 3 учнями в залежності від умов”. Результати сформованості теоретичних

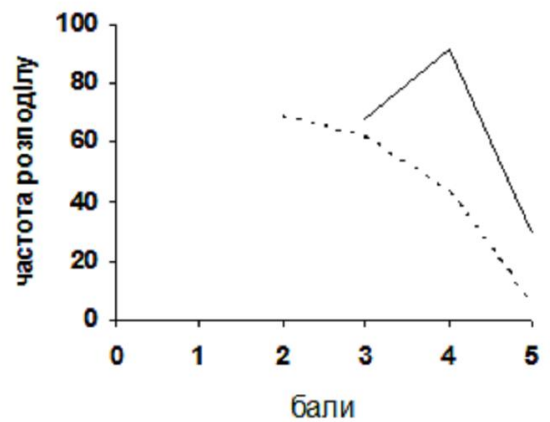

Рис. 1 Розподіл балів за рівнем сформованості мотиваційно-ціннісного критерію готовності студентів до фізкультурно-спортивної діяльності:

контрольна група експериментальна група 


\section{ДОСЛІДНО-ЕКСПЕРИМЕНТАЛЬНА РОБОТА 3 ФОРМУВАННЯ ГОТОВНОСТІ МАЙБУТНІХ УЧИТЕЛІВ ФІЗИЧНОЇ КУЛЬТУРИ ДО ФІЗКУЛЬТУРНО-СПОРТИВНОЇ ДІЯЛЬНОСТІ В ЗАКЛАДАХ СЕРЕДНЬОЇ ОСВІТИ}

знань у майбутніх учителів фізичної культури до і після доводить, що студенти ЕГ досить непогано володіють знаннями про недопустимі явища в спорті (74,2 \%), основами техніки в обраному виді спорту (70,3 \%), студенти КГ відповідно - 41,8 \% та $36,7 \%$.

Результати дослідження показали, що студенти контрольних груп, які не мають спеціальної підготовки до проведення масових спортивних заходів, показали середні результати сформованості теоретичних знань, тоді як студенти експериментальних груп довели високі результати.

Отже, рівень готовності студентів до фізкультурно-спортивної діяльності в загальноосвітніх навчальних закладах за інтелектуально-пізнавальним критерієм у контрольній групі становить (в балах): $\mathrm{H}_{\mathrm{\kappa}}{ }^{0}=3,1$; експериментальній $-\mathrm{H}_{\mathrm{e}}^{0}=3,91$. Різниця між ними склала $16,2 \%$, що впливає на результативність отриманих даних на етапі формувального експерименту.

Наочно отримані результати відображені на рис. 2.

Аналіз рисунку 2 наочно доводить наявність суттєвої різниці між показниками сформованості інтелектуально-пізнавального критерію готовності студентів до фізкультурно-спортивної діяльності у обох групах.

Для виявлення рівня сформованості діяльніснопрактичного критерію використовувалися такі методи: експеримент, самооцінка, тестування, анкетування, тести з фізичної підготовленості та фізичного стану студентів.

Діагностика діяльнісно-практичного критерію здійснювалася за сформованістю професійнопедагогічних умінь. Для того, щоб виявити уміння дидактичної обробки навчального матеріалу

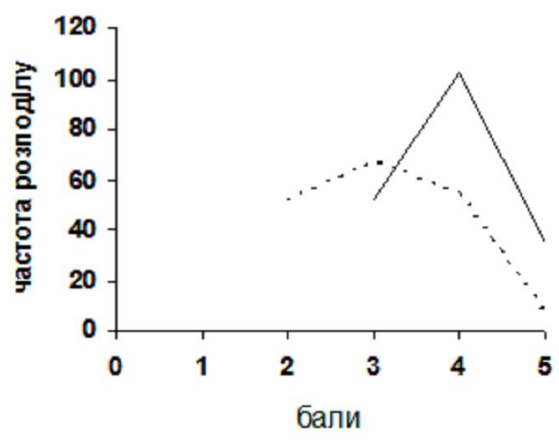

Рис. 2 Розподіл балів за рівнем сформованості інтелектуально-пізнавального критерію готовності студентів до фізкультурно-спортивної діяльності в загальноосвітній школі: контрольна група експериментальна група студентам дали завдання письмово викласти пояснення техніки виконання трьох гімнастичних елементів. Пояснення мало будуватися 3 урахуванням інтелектуальних особливостей дітей, що займаються спортивною гімнастикою більше одного року.

Аналіз даних доводить, що у студентів ЕГ найкраще сформоване уміння володіти адекватною професійною оцінкою і самооцінкою, високий рівень якого складає $39,5 \%$, уміння виявити, усвідомити і усунути допущені помилки в фізкультурно-спортивній діяльності - 37,4 \%, уміння здійснювати спортивно-педагогічну діагностику $-35,7$ \%. На високий рівень за умінням організувати учнів для плідної роботи в спортивних секціях і різних фізкультурноспортивних заходах вийшли студенти КГ - 16,3 \%, умінням дидактичної обробки навчального матеріалу $-7,5 \%$.

Уміння студентів експериментальної групи виявилися більш повно сформовані, більш оригінальні, базувалися на певних закономірностях фізкультурно-спортивної діяльності і всього педагогічного процесу в цілому.

У межах педагогічної практики студенти експериментальної групи проводили практично всі види фізкультурно-спортивних занять, використовували розроблені сюжетно-рольові уроки. Аналіз даних показав, що студенти ЕГ під час педагогічної практики активніше за студентів КГ використовували різні види фізкультурноспортивних заходів.

Експертні оцінки залікового уроку, фізкультурно-оздоровчого заходу на педагогічній практиці показали, що професійні вміння у студентів експериментальної та контрольної груп сформовано на різних рівнях.

Результати дослідження показали, що рівень сформованості професійно-педагогічних умінь на уроці фізичної культури в експериментальній групі високий: в умінні складати конспект уроку, відповідно до його завдань - 86,8 \%, у виборі засобів навчання $86,3 \%$; в умінні підготувати місце занять і організувати учнів - 78,5\%; в умінні попереджати травматизм на уроці - 72,8 \%; інші вміння сформовані на середньому рівні. У контрольній групі уміння складати конспект уроку, відповідно до його завдань сформовано на середньому рівні - 48,7\%; уміння підбирати засоби навчання - 49,8 \%. У інших уміннях проявляється низький рівень ї сформованості.

Отже, рівень готовності студентів до фізкультурно-спортивної діяльності за 


\section{ДОСЛІДНО-ЕКСПЕРИМЕНТАЛЬНА РОБОТА 3 ФОРМУВАННЯ ГОТОВНОСТІ МАЙБУТНІХ УЧИТЕЛІВ ФІЗИЧНОЇ КУЛЬТУРИ ДО ФІЗКУЛЬТУРНО-СПОРТИВНОЇ ДІЯЛЬНОСТІ В ЗАКЛАДАХ СЕРЕДНЬОЇ ОСВІТИ}

діяльнісно-практичним критерієм у контрольній групі складає (в балах): $\mathrm{H}_{\mathrm{k}}{ }^{0}=3,08$; експериментальній $-\mathrm{H}_{\mathrm{k}}^{0}=3,94$. Різниця між ними $17,2 \%$, що значно впливає на результативність отриманих даних під час формувального експерименту.

Наочно отримані результати відображено на рис. 3.

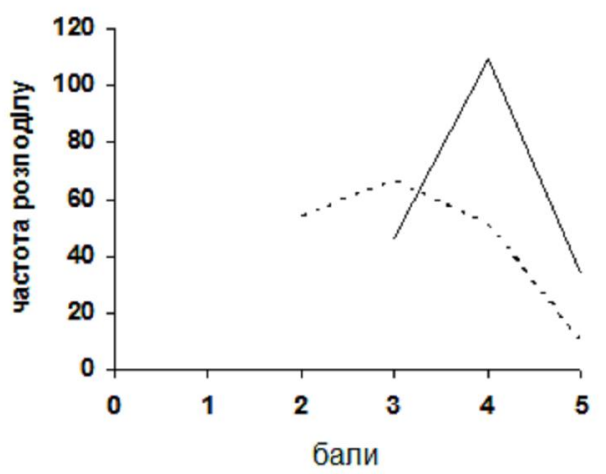

Рис. 3 Розподіл балів за рівнем сформованості діяльнісно-практичного критерію готовності студентів до фізкультурно-спортивної діяльності: ----- контрольна група експериментальна група

Аналіз рисунку 3 наочно доводить наявність суттєвої різниці між показниками сформованості діяльнісно-практичного критерію готовності студентів до фізкультурно-спортивної діяльності у обох групах.

Результати проведеного дослідження 3 визначення рівня готовності майбутніх учителів фізичної культури до фізкультурно-спортивної діяльності в загальноосвітніх навчальних закладах за критеріями дозволило узагальнити отримані дані. Результати дослідження доводять, що середньоарифметична величина МЦ готовності майбутніх учителів фізичної культури до фізкультурно-спортивної діяльності в загальноосвітніх навчальних закладах за діяльнісно-практичним критерієм у КГ складає 2,9 бала, що становить 58,0 \%, IП - 3,1 (62,0 \%), ДП $-3,08$ (61,6 \%), у ЕГ: МЦ $-3,8(76,0 \%)$, IП $_{\text {e }}$ - 3,91 (78,2 \%), ДП $-3,94$ (78,8 \%).

Аналіз вказує, що готовність майбутніх учителів фізичної культури до фізкультурноспортивної діяльності в загальноосвітніх навчальних закладах за мотиваційно-ціннісним критерієм в ЕГ складає 76,0\%, що відповідає високому рівню, КГ - 58,0 \%, що відповідає середньому рівню. Готовність майбутніх учителів фізичної культури до фізкультурно-спортивної діяльності в загальноосвітніх навчальних закладах за інтелектуально-пізнавальним критерієм в ЕГ складає 78,2 \%, що відповідає високому рівню, КГ - 62,0 \%. Це показник середнього рівня. Готовність майбутніх учителів фізичної культури до фізкультурно-спортивної діяльності в загальноосвітніх навчальних закладах за діяльнісно-практичним критерієм у ЕГ складає $78,8 \%$, що відповідає високому рівню, КГ $61,6 \%$. Це показник середнього рівня.

Наочно результати дослідження відображено на рис. 4.

Аналіз рисунку доводить, що у майбутніх учителів фізичної культури спостерігається високий рівень готовності до фізкультурноспортивної діяльності в загальноосвітніх навчальних закладах за мотиваційно-ціннісним, інтелектуально-пізнавальним, діяльніснопрактичним критеріями у експериментальній та середнього у контрольній групах та значну різницю показників між ними. Різниця між мотиваційно-ціннісним критерієм експериментальної та контрольної групи складає $18,0 \%$, інтелектуально-пізнавальним 16,2 \%, діяльнісно-практичним - 17,2 \%. Це означає, що між рівнями готовності майбутніх учителів фізичної культури до фізкультурноспортивної діяльності в загальноосвітніх навчальних закладах за мотиваційно-ціннісним, інтелектуально-пізнавальним, діяльніснопрактичним критеріями існує значна відмінність.

Отже, за результатами порівняльного аналізу початкового та формувального етапів експериментальної роботи спостерігається зміна рівнів готовності майбутніх учителів фізичної культури до фізкультурно-спортивної діяльності експериментальної групи із низького на високий. У контрольній - із низького на середній.

Результати дослідно-експериментальної роботи доводять, що підготовка майбутніх учителів фізичної культури до фізкультурноспортивної діяльності в загальноосвітніх навчальних закладах забезпечувалася ефективними нововведеннями, а відповідно і позитивними змінами у рівнях сформованості їх готовності в ЕГ.

Динаміка рівнів готовності майбутніх учителів фізичної культури до фізкультурно-спортивної діяльності в загальноосвітніх навчальних закладах показана в таблиці 1.

Аналіз таблиці доводить, що за результатами дослідно-експериментальної роботи у студентів ЕГ виявилися більш високі показники рівнів готовності до фізкультурно-спортивної діяльності в загальноосвітніх навчальних закладах, чим у КГ.

Так, в ЕГ високий рівень готовності студентів до фізкультурно-спортивної діяльності зріс 


\section{ДОСЛІДНО-ЕКСПЕРИМЕНТАЛЬНА РОБОТА 3 ФОРМУВАННЯ ГОТОВНОСТІ МАЙБУТНІХ УЧИТЕЛІВ ФІЗИЧНОЇ КУЛЬТУРИ ДО ФІЗКУЛЬТУРНО-СПОРТИВНОЇ ДІЯЛЬНОСТІ \\ В ЗАКЛАДАХ СЕРЕДНЬОЇ ОСВІТИ}

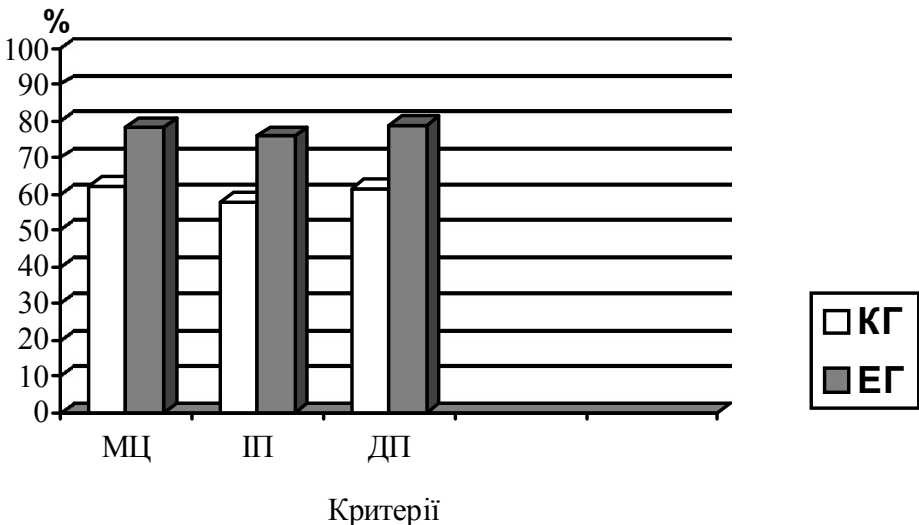

Рис. 4. Рівні готовності майбутніх учителів фізичної культури до фізкультурно-спортивної діяльності в загальноосвітніх навчальних закладах за результатами формувального експерименту

Таблиця 1.

Динаміка рівнів готовності майбутніх учителів фізичної культури до фізкультурноспортивної діяльності в загальноосвітніх навчальних закладах

\begin{tabular}{|l|c|c|c|c|c|c|}
\hline \multicolumn{1}{|c|}{ Рівні } & $\begin{array}{c}\text { Початок } \\
\text { експерименту }\end{array}$ & $\begin{array}{c}\text { Кінець } \\
\text { експерименту }\end{array}$ & Приріст & $\begin{array}{c}\text { Початок } \\
\text { експерименту }\end{array}$ & $\begin{array}{c}\text { Кінець } \\
\text { експерименту }\end{array}$ & Приріст \\
\cline { 2 - 3 } & \multicolumn{2}{|c|}{ КГ } & & ЕГ \\
\hline Низький & $102(56,7 \%)$ & $71(39,5 \%)$ & $-17,2$ & $99(52,4 \%)$ & $22(11,6 \%)$ & $-40,8$ \\
\hline Середній & $76(42,2 \%)$ & $101(56,1 \%)$ & 13,9 & $85(45,0 \%)$ & $131(69,3 \%)$ & 24,3 \\
\hline Високий & $2(1,1 \%)$ & $8(4,4 \%)$ & 3,3 & $5(2,6 \%)$ & $36(19,1 \%)$ & 16,5 \\
\hline
\end{tabular}

порівняно із констатувальним етапом на $16,5 \%$; середній - на 24,3\%; низький зменшився на $40,8 \%$ після проведення формувального експерименту. У КГ високий рівень готовності студентів до фізкультурно-спортивної діяльності зріс на $3,3 \%$; середній - 13,9\%; низький зменшився на $17,2 \%$.

Висновки. Отже, результати реалізації й експериментальної перевірки нововведень у напрямі підготовки майбутніх учителів фізичної культури до фізкультурно-спортивної діяльності в загальноосвітніх навчальних закладах підтвердили їх ефективність, що виражається в позитивній динаміці формування готовності до роботи студентів експериментальних груп у порівнянні 3 контрольними і в більш високому рівні сформованості критеріїв готовності: мотиваційно-ціннісного, інтелектуальнопізнавального, діяльнісно-практичного.

\section{ЛІТЕРАТУРА}

1. Архангельский С. И. Лекции по научной ориентации учебного процесса в высшей школе / С. И. Архангельский. - М.: Высшая школа, 1976. $-200 \mathrm{c}$.
2. Бабанский Ю. К. Проблемы повышения эффективности педагогических исследований: (дидактический аспект) / Ю. К. Бабанский. - М.: Педагогика, 1982. - 192 с.

3. Бабушкин Г. Д. Психология физического воспитания: учеб.- метод. пособ. / Бабушкин Г. Д., Бобровский В. А., Муравьев Ю. Б., Толмачев С. М. - Омск: Юридический ин-т МВД России, 1997. $-168 \mathrm{c}$.

4. Загвязинский В. И. Методология и методика педагогических исследований / В. И. Загвязинский. - Тюмень: ТГУ, 1976. - 85 с.

5. Кыверялг А. А. Методика исследования в профессиональной педагогике / А. А. Кыверялг. - Таллин: Валгус, 1980. - 336 с.

6. Практическая психология для преподавателей / под ред. М. К. Тугушкиной. - М.: Флинта, 1997. $328 \mathrm{c}$.

7. Практикум по общей, экспериментальной и прикладной психологии: учеб. пособ. / [Балин В. Д., Гайда В. К., Гербачевский В. К. и др.]; под ред. А. Л. Крылова, С. А. Маничева. СПб.: Питер, 2000. - 560 с.

8. Основы педагогического мастерства учителя физической культуры / [Решетень И. Н., 87 Молодь і ринок №3 (158), 2018 
Кобер И. Х., Прохорова М. В., Абдулов И. Т.]. Алма-Ата: Руан, 1990. - 64 с.

\section{REFERENCES}

1. Arkhangelskiy, S. I. (1982). Lektsiipo nauchnoy orientatsii uchebnogo protsessa $v$ vysshey shkole [Lectures on the scientific orientation of the educational process in higher education]. Moscov: Higher School, 200 p. [in Russian].

2. Babanskiy, Yu. K. (1982). Problemy povysheniya effektivnosti pedagogicheskikh issledovaniy: (didakticheskiy aspekt) [Problems of improving the effectiveness of pedagogical research: (didactic aspect)]. Moscov: Pedagogy, 192 p. [in Russian].

3. Babushkin, G. D., Bobrovskiy, V. A., Muravyev, Yu. B. \& Tolmachev, S. M. (1997). Psikhologiya fizicheskogo vospitaniya: ucheb.-metod. posob [Psychology of physical education: the teaching method.]. Omsk: Legal Institute of the Ministry of Internal Affairs of Russia, 168 p. [in Russian].

4. Zagvyazinskiy, V. I. (1976). Metodologiya $i$ metodika pedagogicheskikh issledovaniy [Methodology and methods of pedagogical research]. Tyumen: TSU, 85 p. [in Russian].

5. Krylova, A. L. \& Manicheva, S. A. (2000). Praktikum po obshchey, eksperimentalnoy $i$ prikladnoy psikhologii: ucheb. posob. [Workshop on General, Experimental and Applied Psychology: Textbook.]. St. Petersburg: Peter, 560 p. [in Russian].

6. Kyveryalg, A. A. (1980). Metodika issledovaniya $v$ professionalnoy pedagogike [Methods of research in professional pedagogy]. Tallinn: Valgus, 336 p. [in Russian].

7. Resheten, I. N., Kober, I. Kh., Prokhorova, M. V. \& Abdulov, I. T. (1990). Osnovy pedagogicheskogo masterstva uchitelya fizicheskoy kultury [Fundamentals of pedagogical skill of the teacher of physical culture]. Alma-Ata: Rouen, 64 p. [in Russian].

8. Tutushkinoy, M. K. (1997). Prakticheskaya psikhologiya dlya prepodavateley [Practical psychology for teachers]. Moscov: Flinta, 328 p. [in Russian].

Стаття надійшла до редакції 13.02.2018

УДК $378.147-057.36$

DOI:

Yuriy Taymasov, Ph.D. (Pedagogy), Senior Lecturer of the Training Center of Special-purpose of the Main Directorate of the State Service of Ukraine of Extraordinary Situations of Ukraine in Kharkiv region

\section{PHYSICAL TRAINING OFTHE SPECIALISTS OF CIVIL PROTECTION SERVICE AS A SELF-PRESERVATION COMPONENT}

The article presents the problem areas in the special physical training of the specialists of civil protection service, as well as on the development of individual professional qualities and their structural changes in the mental sphere that occur during the assignment tasks. The analysis of existing means of special physical training, revealing and introduction of new professional techniques has been carried out. The model of professional actions, which includes a set of combat tasks, interfering factors and extreme conditions of conducting the educational and professional actions is substantiated, to contribute the development of special physical abilities, formation of professionally important motor skills, increase of psychophysical possibilities that ensure a high level of applied readiness of the civil protection service specialists. The most effective forms of physical trainings by which means are brought up (psychological and emotional stability, courage and determination, persistence and commitment, endurance and self-control, stability of attention, confidence in own forces) are given.

Keywords: the exercises, the researches, modeling, the special physical training, civil protection service. Ref. 8.

Юрій Таймасов, кандидат педагогічних наук, стариий викладач навчального пункту аварійно-рятувального загону спеціального призначення Головного управління ДСНС Украӥни у Харківській області

\section{ФІЗИЧНА ПІДГОТОВКА ФАХІВЦІВ СЛУЖБИ ЦИВІЛЬНОГО ЗАХИСТУ ЯК СКЛАДОВА САМОЗБЕРЕЖЕННЯ}

У статті представлені проблемні місия у спеціальній фізичній підготовиі фахівців служби цивільного захисту, щзодо розвитку як окремих професійно важливих якостей, так $і$ їх структурних змін в психічній сфері, щңо відбуваються під час виконання завдань за призначенням. Проведено аналіз існуючих 